Pesq. Vet. Bras. 37(10):1069-1073, outubro 2017 DOI: $10.1590 / \mathrm{S} 0100-736 \mathrm{X} 2017001000005$

\title{
Phylogenetic characterization of serum plus antibiotic-resistant extraintestinal Escherichia coli obtained from the liver of poultry carcasses in Pernambuco ${ }^{1}$
}

\author{
Renata V. Vaz ${ }^{2}$, Gisele V. Gouveia ${ }^{3}$, Nelito M.J. Andrade ${ }^{2}$, Mateus M. da Costa ${ }^{3}$ \\ and Jose V. Lima-Filho ${ }^{2 *}$
}

\begin{abstract}
Vaz R.V., Gouveia G.V., Andrade N.M.J., Costa M.M. \& Lima-Filho J.V. 2017. Phylogenetic characterization of serum plus antibiotic-resistant extraintestinal Escherichia coli obtained from the liver of poultry carcasses in Pernambuco. Pesquisa Veterinária Brasileira 37(10):1069-1073. Departamento de Biologia, Universidade Federal Rural de Pernambuco, Rua Dom Manoel de Medeiros s/n, Dois Irmãos, Recife, PE 52171-900, Brazil. E-mail: jose.mlimafo@ufrpe.br

In this study, avian extraintestinal Escherichia coli obtained from the liver of poultry carcasses approved for human consumption in the State of Pernambuco-Brazil were tested for antibiotic plus serum-resistance. Liver samples $(n=110)$ were obtained from one slaughterhouse and 88 bacterial isolates were identified as Escherichia coli. The antibiotic-resistance profiles of antibiotics used in human and/or veterinary practice were accessed by the disk-diffusion method. Phenotypes with high resistance to streptomycin (84.0\%), tetracycline $(44.7 \%)$, amikacin $(29.8 \%)$, gentamicin $(21.3 \%)$ and ciprofloxacin $(21.3 \%)$ were identified. Resistance to antibiotics such as ceftazidime, amoxicillin-clavulanic acid and imipenem was also recorded. Twenty isolates with distinct antibiotic-resistance and susceptibility profiles were selected for serum resistance assays, phylogenetic characterization and detection of the iss gene. We have shown that multidrug resistant isolates were often simultaneously resistant to broiler and human sera. Phylogenetic characterization of serum- plus antibiotic-resistant isolates have shown three belonging to group $\mathrm{D}$, eleven to group B1, one to group B2, and five to group A. We concluded that commensal E. coli strains isolated from the liver of healthy poultry carcasses can harbor and potentially share multidrug- plus virulence genes found in pathogenic pathotypes. This suspicion was not related to specific phylogenetic groups or presence of the iss gene.
\end{abstract}

INDEX TERMS: Phylogenetic characterization, antibiotic-resistancy, Escherichia coli, poultry infection, Pernambuco ExPEC, colibacillosis.

RESUMO.- [Caracterização filogenética de Escherichia coli extraintestinal soro- e antibiótico-resistentes isoladas do fígado de carcaças de frango em Pernambuco.] Neste estudo, isolados de Escherichia coli extraintestinal aviária obtidos a partir do fígado de carcaças de aves apro-

\footnotetext{
${ }^{1}$ Received on June 15, 2016.

Accepted for publication on February 2, 2017

${ }^{2}$ Departamento de Biologia, Universidade Federal Rural de Pernambuco (UFRPE), Rua Dom Manoel de Medeiros s/n, Recife, PE 52171-900, Brazil. *Corresponding author: jose.mlimafo@ufrpe.br

${ }^{3}$ Laboratório de Microbiologia e Imunologia Animal, Universidade Federal do Vale do São Francisco (Univasf), Rua João Ferreira dos Santos s/n, Bairro Campestre, Petrolina, PE 56304-917, Brazil.
}

vadas para consumo humano no Estado de Pernambuco-Brasil foram testados para resistência a antibióticos e soro. As amostras de fígado $(\mathrm{n}=110)$ foram obtidas de um abatedouro, sendo 88 isolados bacterianos identificados como Escherichia coli. Os perfis de resistência a antibióticos de uso humano e/ou veterinário foram determinados pelo método de disco-difusão. Foram identificados fenótipos com alta resistência à estreptomicina $(84,0 \%)$, tetraciclina $(44,7 \%)$, amicacina $(29,8 \%)$, gentamicina $(21,3 \%)$ e ciprofloxacina $(21,3 \%)$. A resistência a antibióticos utilizados na medicina humana e/ou veterinária, tais como a ceftazidima, amoxicilina-ácido clavulânico, estreptomicina e imipenem também foi registrada. Vinte amostras com perfis distintos de resistência/sensibilidade a antibióticos 
foram selecionadas para os ensaios de resistência ao soro, caracterização filogenética e detecção do gene iss. Foi demonstrado que isolados resistentes a múltiplas drogas foram também simultaneamente resistentes ao soro de frangos e ao soro humano. A caracterização filogenética desses isolados mostraram três pertencentes ao grupo D, onze ao grupo B1, um ao grupo B2 e cinco ao grupo A. Conclui-se que E. coli comensais isoladas do fígado de carcaças de aves saudáveis podem abrigar e potencialmente compartilhar genes de resistência a drogas e de virulência encontrados em patotipos patogênicos. Essa suspeita não foi relacionada com grupos filogenéticos específicos ou com a presença do gene iss.

TERMOS DE INDEXAÇ̃̃O: Caracterização filogenética, Escherichia coli, resistência antibiótica, frango, Pernambuco, ExPEC, colibacilose.

\section{INTRODUCTION}

The inclusion of antibiotics in broiler feed is often associated with improved growth rate, feed efficiency and increased animal production. However, this practice has been banned in developed countries due to possibility of transferring conjugative plasmids and transposons between bacterial strains of the gut microbiota (Aarestrup et al. 2001). Although Brazil has been the world's largest exporter of chicken meat since 2004, few studies were performed to clarify the risk for human health from consuming poultry contaminated by drug-resistant Escherichia coli. Furthermore, antimicrobials of different classes are authorized for non-veterinary usage in the country (Brasil 2015). Since some of these drugs are of the same class of those indicated to human use, the risk of producing multidrug-resistant pathotypes through the food chain is significant.

The spread of infections caused by extraintestinal pathogenic Escherichia coli (ExPEC) is among the main problems of the modern poultry industry. ExPEC pathotypes such as avian pathogenic E. coli (APEC) can cause multifactorial diseases that affect chickens, turkeys, parrots and other bird species (Delicato et al. 2003). Virulence mechanisms includes iron acquisition systems, production of toxins, adhesion capacity, presence of capsular antigens and temperature-sensitive hemagglutinins (Rodriguez-Siek et al. 2005). However, resistance to serum complement is considered the hallmark of virulence for APEC strains and serum sensitive bacteria often are unable to colonize internal organs. Accordingly, the increased serum survival gene (iss), found in ColV and ColBM plasmids, has been used as virulence marker together with other candidate genes for diagnostic purposes (Johnson et al. 2006).

Human serum resistance among ExPEC allows survival in the host's bloodstream and can potentially lead to disseminated infections. Although the potential of the APEC pathotype to cause human infections through the food chain is unclear, it can colonize the intestinal tract and enhance virulence gene transfer to human strains. For example, APEC strains and urogenital pathogenic E. coli (UPEC) causing human infections were shown to share large genomic sequences (Johnson et al. 2007, Kariyawasam et al. 2007).
In a previous study, we have shown that multidrug-resistant E. coli harboring the iss gene obtained from poultry carcasses may resist the human serum and cause pathogenesis in the murine model (Lima-Filho et al. 2013). In this study, avian extraintestinal Escherichia coli obtained from the liver of poultry carcasses approved for human consumption in the State of Pernambuco-Brazil were tested for antibiotic plus serum-resistance. Phylogenetic characterization serum- plus antibiotic-resistant isolates was conducted.

\section{MATERIALS AND METHODS}

Sample collection. Three lots of poultry carcasses were analyzed at random, as follows: lot $1(n=50)$; lot $2(n=30)$ and lot $3(n=30)$. Liver samples $(n=110)$ without macroscopic alterations and approved for human consumption were obtained from one slaughterhouse in the state of Pernambuco, Brazil. The livers were obtained aseptically just after the evisceration of carcasses at one single location in the poultry processing plant. The samples were packed in sterile Petri dishes and kept into sealed bags while transported in isothermal food containers containing recyclable ice. Samples were processed in the Microbiology and Immunology Laboratory (Department of Biology, Pernambuco Federal Rural University) no longer than 120 min after collection. These samples were macerated $(1: 10 ; \mathrm{w}: \mathrm{v})$ in brain heart infusion broth (BHI) for enrichment and incubated overnight at $37^{\circ} \mathrm{C}$. Then, suspected cultures were seeded on eosin methylene blue agar (EMB), and were incubated overnight at $37^{\circ} \mathrm{C}$. Typical colonies of green color with metallic luster were submitted to Citrate, VM-VP and indole biochemical tests and confirmed phenotypically to be $E$. coli (Franco, de Melo, G., Landgraf 2004).

Antibiotic-resistance assays. The resistance profiles to antimicrobials of veterinary and/or human use were carried out by the standard disk-diffusion method (CLSI 2012). All tests were carried out in duplicate against twelve antimicrobials $\left(\mathrm{Cecon}^{\circledR}\right)$ : amoxicillin-clavulanic acid $(10 \mu \mathrm{g})$, cefalotin $(30 \mu \mathrm{g})$, ceftazidim $(30 \mu \mathrm{g})$, aztreonam $(30 \mu \mathrm{g})$, imipenem $(10 \mu \mathrm{g})$, gentamicin $(10 \mu \mathrm{g})$, amikacin $(30 \mu \mathrm{g})$, streptomycin $(10 \mu \mathrm{g})$, ciprofloxacin $(5 \mu \mathrm{g})$, levofloxacin $(5 \mu \mathrm{g})$, chloramphenicol $(30 \mu \mathrm{g})$, tetracycline $(30 \mu \mathrm{g})$. The results were interpreted as sensitive (S), moderately sensitive (I) or resistant (R). The breakpoints for resistance were those recommended by CLSI. Multidrug resistance was determined when bacterial isolates were resistant to antimicrobials of at least three different classes (Magiorakos et al. 2012). The isolates obtained from a single sample with an identical antibiotic resistance/sensitivity profile were treated as a single strain. In this case, bacterial replicates were not conducted. Twenty isolates $(2,9,12,51,52$, $53,54,56,57,59,60,61,62,63,64,65,66,71,72,73)$ with distinct antibiotic-resistance profiles were selected for serum resistance assays, phylogenetic characterization and detection of the iss gene.

Phylogenetic characterization. Phylogenetic analysis was performed in the Microbiology and Animal Immunology Laboratory (Vale do São Francisco Federal University, Petrolina, PE), as follows: genomic DNA from E. coli was obtained by thermal lysis. The primers were those described by Clermont et al. (2000):

\footnotetext{
Chua (279 bp) - Forward:5' GACGAACCAACGGTCAG GAT 3' Reverse: 5' TGCCGCCAGTACCAAAGACA 3'

YjaA (211 bp) - Forward: 5' TGAAGTG TCAGGAGACGCTG 3' Reverse: 5' ATGGAGAATGCGTTCCTCAAC 3'

TspE4C2 (152 bp) - Forward: 5’ GAGTAATGTCGGGGCATTCA Reverse: 5' CGCGCCAACAAAGTATTACG 3'
} 
The following conditions were used: denaturation for $5 \mathrm{~min}$ at $94^{\circ} \mathrm{C}, 30$ cycles of $30 \mathrm{~s}$ at $94^{\circ} \mathrm{C}, 30 \mathrm{~s}$ at $55^{\circ} \mathrm{C}$ and 30 s at $72^{\circ} \mathrm{C}$, and a final extension for $7 \mathrm{~min}$ at $72^{\circ} \mathrm{C}$. The PCR products were visualized on $1.5 \%$ agarose gel stained with ethidium bromide.

Detection of the iss gene. Detection of the iss gene was performed by PCR according to Johnson et al. (2008):

\section{iss (323 bp) - Forward: 5' CAGCAACCCGAACCACTTGATG 3' Reverse: 5' AGCATTGCCAGAGCGGCAGAA 3'}

The following conditions were used: denaturation at $94^{\circ} \mathrm{C} 4$ min, 30 cycles of $45 \mathrm{~s}$ at $94^{\circ} \mathrm{C}, 45 \mathrm{~s}$ at $55^{\circ} \mathrm{C}$ and $60 \mathrm{~s}$ at $72^{\circ} \mathrm{C}$, and a final extension time of $7 \mathrm{~min}$ at $72^{\circ} \mathrm{C}$. The PCR products were visualized on $1.5 \%$ agarose gel stained with ethidium bromide.

Serum-resistance assays. Serum resistance was evaluated among selected $E$. coli strains $(n=20)$ presenting distinct antibiotic resistance/susceptibility profiles, according to the method adapted from Samuelsen et al. (2004). Mixed preparations containing human or broiler sera $(190 \mu \mathrm{L})$ and E. coli $\left(10 \mu \mathrm{L}, 10^{7} \mathrm{CFU} / \mathrm{mL}\right)$ were cultured together at $37^{\circ} \mathrm{C}$ for $6 \mathrm{~h}$. At different time periods, aliquots of $0.1 \mathrm{~mL}$ were plated on MacConkey agar for enumeration of the colony forming units. A commensal human strain of E. coli (strain EMO), sensitive to human and broiler serum was kindly provided by Prof. Jacques Nicoli (UFMG), and used as control. All strains were exposed to normal or heat-treated serum $\left(57^{\circ} \mathrm{C} / 30 \mathrm{~min}\right)$.

\section{RESULTS AND DISCUSSION}

After blind analyses of experiments, each lot of poultry carcasses was identified as sourced from broiler raised in three different farms (Table 1). E. coli was identified in 88 out of 110 liver samples and the highest resistance phenotypes were to streptomycin (84.0\%), tetracycline (44.7\%), amikacin $(29.8 \%)$, ceftazidime (21.3\%), gentamicin (21.3\%) and ciprofloxacin $(21.3 \%)$ (Table 1$)$. The overall drug resistance varied from one to six antimicrobials. However, multi-drug resistant strains were prevalent among isolates from lots 1 (Farm 1: 24 out of 50; 48\%) and 2 (Farm 2: 12 out of $30 ; 40 \%$ ) whereas only 2 out of 30 strains in lot 3 (Farm 3: $6.7 \%$; isolates 92 and 104) have shown multidrug-resistance (Table 1). Twenty isolates with distinct antibiotic/resistance profiles were selected for serum resistance assays. The phylogenetic characterization of these E. coli strains showed three belong to group D, one to group B2, eleven to group B1, and five to group A. But the iss gene was confirmed in only $35 \%$ of isolates (Table 2). Simultaneous resistance to broiler plus human sera reached 9 out of 10 multidrug resistant isolates (Table 2).
Previous studies have shown a high percentage of $E$. coli of avian origin with resistance phenotypes to aminoglycosides, tetracyclines, cephalosporins and fluoroquinolones (Lambie et al. 2000, Van den Bogaard et al. 2001). Our results show that the majority of avian isolates were resistant to drugs used in both veterinary and human hospitals such as gentamicin, amikacin, ciprofloxacin and tetracycline. Accordingly, a large number of strains were resistant to ciprofloxacin, a fluoroquinolone that is commonly used to treat infections in humans due to low toxicity and broad spectrum activity (Livermore et al. 2002, Maslow et al. 2004). Resistance to antibiotics such as amoxicilin-clavulanic acid, ceftazidime and streptomycin was also significant. In particular, the detection of resistance to imipenem is of concern since this drug is often used as ultimate therapeutic choice against severe human gram-negative infections (Morrill et al. 2015). Nevertheless, none of antibiotics was effective against all isolates, with levofloxacin producing the highest overall antibiotic-susceptibility rate (87.2\%).

As expected, isolates harboring the iss gene and presumptively identified as ExPEC of APEC pathotype were

Table 2. Phylogenetic characterization and serum resistance of selected avian Escherichia coli with distinct antibiotic resistance/susceptibility profiles

\begin{tabular}{|c|c|c|c|c|c|}
\hline $\begin{array}{c}\text { Class/ } \\
\text { number of } \\
\text { antimicrobials }\end{array}$ & $\begin{array}{c}\text { E. coli } \\
\text { isolates }\end{array}$ & $\begin{array}{c}\text { Avian serum } \\
\text { resistance } \\
(\mathrm{CFU} / \mathrm{mL})^{*}\end{array}$ & $\begin{array}{c}\text { Human serum } \\
\text { resistance } \\
(\mathrm{CFU} / \mathrm{mL})\end{array}$ & $\begin{array}{l}\text { Phylogenetic } \\
\text { Group }\end{array}$ & $\begin{array}{l}\text { Presence } \\
\text { of gene } \\
\text { iss }\end{array}$ \\
\hline $4 / 6$ & 2 & $\geq 1 \times 10^{4}$ & $\geq 1 \times 10^{4}$ & D & + \\
\hline $5 / 6$ & 9 & $\geq 1 \times 10^{6}$ & $\geq 1 \times 106$ & A & - \\
\hline $4 / 6$ & 12 & $\geq 1 \times 10^{6}$ & $\geq 1 \times 10^{6}$ & A & _- \\
\hline $5 / 6$ & 54 & $\geq 1 \times 10^{6}$ & $\geq 1 \times 10^{6}$ & B1 & + \\
\hline $4 / 6$ & 57 & $\geq 1 \times 10^{6}$ & $\geq 1 \times 10^{6}$ & B1 & - \\
\hline $4 / 4$ & 51 & $\geq 1 \times 10^{3}$ & $\geq 1 \times 10^{3}$ & B1 & _- \\
\hline $4 / 4$ & 59 & $\geq 1 \times 10^{2}$ & $\geq 1 \times 10^{5}$ & B1 & _- \\
\hline $4 / 4$ & 71 & $\geq 1 \times 10^{6}$ & $\geq 1 \times 10^{6}$ & B1 & - \\
\hline $4 / 4$ & 73 & $\leq 1 \times 10^{1}$ & $\geq 1 \times 10^{6}$ & B1 & - \\
\hline $3 / 4$ & 72 & $\leq 1 \times 10^{1}$ & $\leq 1 \times 10^{1}$ & $\mathrm{D}$ & _- \\
\hline $2 / 2$ & 56 & $\geq 1 \times 10^{6}$ & $\leq 1 \times 10^{1}$ & A & - \\
\hline $2 / 2$ & 60 & $\geq 1 \times 10^{5}$ & $\geq 1 \times 10^{5}$ & B2 & + \\
\hline $2 / 2$ & 62 & $\geq 1 \times 10^{6}$ & $\geq 1 \times 10^{4}$ & B1 & + \\
\hline $1 / 2$ & 61 & $\geq 1 \times 10^{3}$ & $\geq 1 \times 10^{3}$ & $\mathrm{D}$ & + \\
\hline $1 / 1$ & 53 & $\leq 1 \times 10^{1}$ & $\leq 1 \times 10^{1}$ & B1 & - \\
\hline $1 / 1$ & 63 & $\leq 1 \times 10^{1}$ & $\geq 1 \times 10^{4}$ & A & _- \\
\hline $1 / 1$ & 65 & $\geq 1 \times 10^{5}$ & $\leq 1 \times 10^{1}$ & B1 & + \\
\hline $1 / 1$ & 66 & $\leq 1 \times 10^{1}$ & $\geq 1 \times 10^{3}$ & A & - \\
\hline 0 & 52 & $\leq 1 \times 10^{1}$ & $\leq 1 \times 10^{1}$ & B1 & _ \\
\hline 0 & 64 & $\leq 1 \times 10^{1}$ & $\geq 1 \times 10^{4}$ & B1 & + \\
\hline
\end{tabular}

* Bacterial cell counts following $6 \mathrm{~h}$ exposure to broiler or human sera.

Table 1. Antibiotic-resistance profile of avian extraintestinal Escherichia coli from the liver of poultry carcasses

\begin{tabular}{|c|c|c|c|c|c|c|c|c|c|}
\hline \multirow{2}{*}{$\begin{array}{c}\text { Antimicrobial } \\
\text { class }\end{array}$} & \multirow[t]{2}{*}{ Antimicrobials } & \multirow{2}{*}{$\begin{array}{c}\text { Disc content } \\
(\mu \mathrm{g})\end{array}$} & \multirow{2}{*}{$\begin{array}{c}\text { Resistance } \\
\text { breakpoint (mm) }\end{array}$} & \multirow[t]{2}{*}{$\mathrm{S} * \%$} & \multirow[t]{2}{*}{$\mathrm{I} \%$} & \multirow[t]{2}{*}{$\mathrm{R} \%$} & \multicolumn{3}{|c|}{ Resistant isolates } \\
\hline & & & & & & & Lot $1 /$ Farm 1 & Lot 2/Farm 2 & Lot $3 /$ Farm 3 \\
\hline Penicillin & $\begin{array}{l}\text { Amoxicillin- } \\
\text { clavulanic acid }\end{array}$ & 10 & $\leq 13$ & 45.7 & 38.3 & 15.9 & $8,9,12,13,26,28,38,49$ & $51,54,69,73$ & $93,94,101$ \\
\hline \multirow[t]{2}{*}{ Cephalosporin } & Cefalotin & 30 & $\leq 14$ & 77.6 & 13.8 & 8.5 & $2,7,17,49$ & $51,55,73$ & 103 \\
\hline & Ceftazidim & 30 & $\leq 17$ & 39.4 & 36.4 & 21.3 & $\begin{array}{c}6,10,12,15,19,24 \\
38,46,47,48,49,50\end{array}$ & $54,68,71,72,74$ & $92,98,103$ \\
\hline Monobactam & Aztreonam & 30 & $\leq 17$ & 62.8 & 9.6 & 19.1 & $\begin{array}{c}7,8,10,15,19,38 \\
48,49,50\end{array}$ & $\begin{array}{l}54,57,59,65 \\
68,71,72,77\end{array}$ & 105 \\
\hline Carbapenem & Imipenem & 10 & $\leq 19$ & 46.8 & 40.4 & 12.8 & $6,8,12,24,31$ & $58,59,76,79$ & $92,95,104$ \\
\hline Aminoglycoside & Gentamicin & 10 & $\leq 12$ & 72.3 & 6.4 & 21.3 & $\begin{array}{c}2,6,7,9,11,12,13,15,24 \\
32,38,41,46,48,49,50\end{array}$ & $54,57,68$ & 106 \\
\hline
\end{tabular}


resistant to avian serum (except for strain 64). But isolates lacking this gene were also resistant to the human and broiler sera, and therefore other genes may be involved in virulence. Ewers et al. (2009), who compared strains from diseased chickens with fecal E. coli strains from clinically healthy chickens, found no relationship between resistance to bird serum and virulence of the APEC pathotype. On the other hand, in this study, a significant number of multidrug resistant avian $E$. coli were simultaneously resistant to human and broiler serum, which clearly demonstrates a zoonotic risk. Extraintestinal pathogenic E. coli strains are commonly associated with the group B2, and less often with group D (Russo \& Johnson 2000). Nevertheless, sequencing of APEC-related plasmid pAPEC-1 has shown human ExPEC-associated genes and horizontal gene transfer between human and bird strains (Moulin-Schouleur et al. 2007). Here E. coli isolates were distributed in phylogenetic group B2, D, A and B1. Thus, it was clear that serum-resistant commensal strains, e.g., those belonging to group $\mathrm{A}$ and B1, can also harbor and possibly share virulence genes such as the iss.

Previously, Rodriguez-Siek et al. (2005) observed the presence of APEC isolates in phylogenetic group A, recognized by being composed primarily of commensal strains. Moulin-Schouleur et al. (2007) found APEC strains assigned to group B1 and B2 whereas Ewers et al. (2009) found similar distributions of bird serum resistant strains in phylogenetic group A, B1, B2, and D. Kobayashi et al. (2011) analyzed $E$. coli isolated from chicken meat obtained in retail shops, assigning the majority to group A. In this study, multidrug and/or human serum resistance was spread among isolates from B1, A, and D phylogenetic groups. Although the number of isolates submitted to serum resistant assays and phylogenetic characterization were not high, the data reinforce that multidrug plus serum resistant isolates have been introduced in the food-chain.

\section{CONCLUSIONS}

Taken together, our data indicate that commensal $E$. coli strains isolated from the liver of poultry carcasses in Pernambuco-Brazil can harbor and potentially share multidrug- plus virulence genes found in pathogenic pathotypes.

This suspicion was not related to specific phylogenetic groups or presence of the iss gene. Since, in the present study, the lack of macroscopic alterations had not shown a clue about the presence of extraintestinal Eschereichia coli and/ or colibacillosis, the implementation of more rigorous food surveillance can potentially decrease the likelihood of food outbreaks.

Acknowledgements.- We thank the Foundation for Science and Technology of Pernambuco (FACEPE) for the scholarship granted to the first author.

\section{REFERENCES}

Aarestrup F.M., Seyfarth A.M., Emborg H.D. \& Pedersen K. 2001. Effect of abolishment of the use of antimicrobial agents for growth promotion on occurrence of antimicrobial resistance in fecal enterococci from food animals in Denmark. Antimicrob. Agents Chemother. 45:2054-2059.

Brasil 2015. Ministério da Agricultura, Pecuária e Abastecimento. Avail- able in <http://www.agricultura.gov.br/animal/alimentacao/aditivos/ aditivos-autorizados> Accessed on Nov. 24, 2016.

Clermont O., Bonacorsi S. \& Bingen E. 2000. Rapid and simple determination of the Escherichia coli phylogenetic group. Appl. Environ. Microbiol. 10:4555-4558.

CLSI 2012. Performance Standards for Antimicrobial Susceptibility Testing: twenty-second informational supplement. Clinical and Laboratory Standards Institute CLSI Document M100-S22 and M2-A8.

Delicato E.R.B.G., De Brito L.C. \& Vidotto M.C. 2003. Virulence -associated genes in Escherichia coli isolates from poultry with colibacillosis. Vet. Microbiol. 94:97-103.

Ewers C., Antão E.M., Diehl I., Philipp H.C. \& Wieler L.H. 2009. Intestine and environment of the chicken as reservoirs for extraintestinal pathogenic Escherichia coli strains with zoonotic potential. Appl. Environ. Microbiol. 75:184-192.

Franco B.D., De Melo G. \& Landgraf M. 2004. Microbiologia dos Alimentos, Ed. Atheneu, São Paulo.

Johnson T.J., Johnson S.J. \& Nolan L.K. 2006. Complete DNA sequence of a ColBM plasmid from avian pathogenic Escherichia coli suggests that it evolved from closely related ColV virulence plasmids. J. Bacteriol. 188: 5975-59783.

Johnson T.J., Kariyawasam S., Wannemuehler Y., Mangiamele P., Johnson S.J., Doetkott C., Skyberg J.A., Lynne A.M., Johnson J.R. \& Nolan L.K. 2007. The genome sequence of avian pathogenic Escherichia coli strain 01:K1:H7 shares strong similarities with human extraintestinal pathogenic E. coli genomes. J. Bacteriol. 189:3228-3236.

Johnson T.J., Wannemuehler Y.M. \& Nolan L.K. 2008. Evolution of the iss gene in Escherichia coli. Appl. Environ. Microbiol. 74:2360-2369.

Kariyawasam S., Scaccianoce J. \& Nolan L.K. 2007. Common and specific genomic sequences of avian and human extraintestinal pathogenic Escherichia coli as determined by genomic subtractive hybridization. BMC Microbiol. 7:81.

Kobayashi R.K.T., Aquino I., Ferreira A.L.D.S. \& Vidotto M.C. 2011. EcoR phylogenetic analysis and virulence genotyping of avian pathogenic Escherichia coli strains and Escherichia coli isolates from commercial chicken carcasses in southern Brazil. Foodborne Pathog. Dis. 8:631634.

Lambie N., Ngeleka M., Brown G. \& Ryan J. 2000. Retrospective study on Escherichia coli infection in broilers subjected to postmortem examination and antibiotic resistance of isolates in Trinidad. Avian Dis. 44:155160.

Lima-Filho J.V., Martins L.V., Nascimento D.C.D.O., Ventura R.F., Batista J.E., Silva A.F., Ralph M.T., Vaz R.V., Rabello C.B., Silva M. \& Evêncio-Neto J. 2013. Zoonotic potential of multidrug-resistant extraintestinal pathogenic Escherichia coli obtained from healthy poultry carcasses in Salvador, Brazil. Braz. J. Infect. Dis. 17:54-61.

Livermore D.M., James D., Reacher M. \& Graham C. 2002. Trends in fluoroquinolone (ciprofloxacin) resistance in enterobacteriaceae from bacteremias, England and Wales, 1990-1999. Emerg. Infect. Dis. 8: $473-478$.

Magiorakos A.P., Srinivasan A., Carey R.B., Carmeli Y., Falagas M.E., Giske C.G., Harbarth S., Hindler J.F., Kahlmeter G., Olsson-Liljequist B., Paterson D.L., Rice L.B., Stelling J., Struelens M.J., Vatopoulos A., Weber J.T. \& Monnet D.L. 2012. Multidrug-resistant, extensively drug-resistant and pandrug-resistant bacteria: an international expert proposal for interim standard definitions for acquired resistance. Clin. Microbiol. Infect. 18:268-281.

Maslow J.N., Lautenbach E., Glaze T., Bilker W. \& Johnson J.R. 2004. Colonization with extraintestinal pathogenic Escherichia coli among nursing home residents and its relationship to fluoroquinolone resistance. Antimicrob. Agents Chemother. 48:3618-3620.

Morrill H.J., Pogue J.M., Kaye K.S. \& LaPlante K.L. 2015. Treatment Options for Carbapenem-Resistant Enterobacteriaceae Infections. Open Forum Infect. Dis. 2:ofv050.

Moulin-Schouleur M., Répérant M., Laurent S. \& Brée A. 2007. Extraintestinal pathogenic Escherichia coli strains of avian and human origin: Link 
between phylogenetic relationships and common virulence patterns. J. Clin. Microbiol. 45:3366-3376.

Rodriguez-Siek K.E., Giddings C.W., Doetkott C., Johnson T.J. \& Nolan L.K. 2005. Characterizing the APEC pathotype. Vet. Res. 36:241-56.

Russo T.A. \& Johnson J.R. 2000. Proposal for a new inclusive designation for extraintestinal pathogenic isolates of Escherichia coli: ExPEC. J. Infect. Dis. 181:1753-1754.
Samuelsen Ø., Haukland H.H., Ulvatne H. \& Vorland L.H. 2004. Anti-complement effects of lactoferrin-derived peptides. FEMS Immunol. Med. Microbiol. 41:141-148.

Van den Bogaard A.E., London N., Driessen C., Stobberingh E.E., Bogaard A.E.. Van den, London N., Driessen C. \& Stobberingh E.E. 2001. Antibiotic resistance of faecal Escherichia coli in poultry, poultry farmers and poultry slaughterers. J. Antimicrob. Chemother. 47:763-771. 